\title{
Hubungan Kesesuaian Pendapatan dan Belanja Daerah Provinsi Kalimantan Timur
}

\author{
Abd.Rachim AF. \\ Universitas Widya Gama Mahakam Samarinda \\ abdrachim@uwgm.ac.id
}

\begin{abstract}
The measurement of regional government budget can be the foundation for government to run government, carry out development and develop society. More over to measure the accomplishment, a ratio analysis on regional government budges was applied, by comparing direct and indirect expenditure as well as grouping the expense purpose expenses for apparatus and expenses for public need considering the limited document availability, the researcher investigated regional government budget performance in 2013.

As the result, indirect expenditure roade up $49,39 \%$ of the total of regional goverment budget, and the direct expenditure made up 50,61\% which include honorarium payment, business trip cost for apparatus need consequently, the expenses for apparatus increased cato $54,86 \%$ meanwhile, expenses for public development decreased int 45,37\%

Keyword : The measurement of regional government budget for apparatus and public expenditvte

Abstrak

Pengukuran kinerja belanja daerah dapat dijadikan sebagai tolak ukur pemerintah daerah dalam menjalankan roda pemerintahan,pembangunnan dan kemasyarakatan.Cara yang digunakan untuk mengukur keberhasilan adalah analisis rasio belanja daerah, membandingkan belanja tidak langsung dan belanja langsung serta dapat pula mengkelompokan anggaran yang fokus untuk belanja daerah digunakan sebagai belanja aparatur dan belanja publik. Mengingat keterbatasan dokumen yang diperoleh, maka dilakukan kajian kinerja belanja daerah tahun 2013.

Hasilnya Penggunaan belanja tidak langsung sebesar 49,39 \% dari jumlah belanja daerah, dan belanja langsung sebesar 50,61 \%.Penggunaan belanja langsung ternyata didalam penjabaran terdapat honorair dan belanja perjalanan dinas untuk kepentingan aparatur. Hasilnya untuk belanja Aparatur naik menjadi sebesar 54,86 \% dan sedangkan belanja pembangunan dan kemasyarakatan atau publik turun menjadi sebesar 45,37\%
\end{abstract}

Kata Kunci : Pengukuran kinerja belanja daerah untuk aparatur dan publik. 
1. Bahan disajikan pada acara professor present pada tanggal 2 Mei di hotel selyca Samarinda

2. Guru besar ekonomi pembanguna dan keuangan negara \& daerah / Rektor Universitas Widyagama Mahakam Samarinda

\section{A. PEDAHULUAN}

1. Latar Belakang

\section{a. Pendapatan Daerah}

Berdasarkan Undang-undang nomor 32 tahun 2004 tentang pemerintah daerah, APBD didefinisikan sebagai rencana operasional keuangan pemerintah daerah, dimana satu pihak menggambarkan perkiraan pengeluaran guna membiayai kegiatan dan proyek daerah dalam satu tahun anggaran tertentu dan dipihak lain menggambarkan perkiraan penerimaan dan sumber penerimaan daerah guna menutupi pengeluaran yang dimaksud.

Standar Akuntansi Pemerintahan, Pendapatan Daerah adalah semua penerimaan kas yang menjadi hak daerah dan diakui sebagai penambah nilai kekayaan bersih dalam satu tahun anggaran dan tak perlu dibayar lagi oleh pemerintah. Kelompok pendapatan terdiri atas:

a. Pendapatan asli daerah (PAD) adalah pendapatan daerah yang dipungut berdasarkan peraturan daerah sesuai dengan peraturan perundang-undangan.

b. Dana perimbangan adalah dana yang bersumber dari pendapatan APBN yang dialokasikan kepada daerah dalam rangka pelaksanaan desentralisasi.

c. Lain-lain pendapatan yang sah adalah pendapatan lain-lain yang dihasilkan dari bantuan dan dana penyeimbang dari pemerintah pusat.

Analisis Pendapatan Daerah bertujuan untuk menganalisis komponen. Pendapatan Daerah sebagai sumber penerimaan daerah dalam rangka menutupi kebutuhan belanja.Analisis ini penting dalam rangka melihat gambaran kondisi pendapatan daerah Provinsi Kalimanta Timur yang ditinjau dari berbagai sudut pandang.

Dalam melakukan analisis pendapatan, terdapat empat rasio yang akan dilihat secara detail, yaitu rasio pajak (tax ratio), rasio pajak per kapita (tax per capita), ruang fiskal (fiscal space), serta ketergantungan fiskal. Dua rasio pertama menyoroti pajak daerah 
sebagai sumber utama PAD yang diperbandingkan dengan PDRB dan jumlah penduduk, sedangkan dua rasio terakhir membahas kemampuan daerah dalam menghasilkan Pendapatan Daerah guna memenuhi kebutuhan belanja serta kemampuan daerah dalam menghasilkan pendapatan daerah dengan tidak tergantung dari pihak eksternal.

Pengukuran kinerja belanja daerah dapat dijadikan sebagai tolak ukur pemerintah daerah dalam menjalankan roda pemerintahan,pembangunnan dan kemasyarakatan. Satu dari bebagai cara yang digunakan untuk mengukur keberhasilan adalah menggunakan analisis rasio belanja daerah dengan cara membandingkan belanja tidak langsung dan belanja langsung serta dapat pula mengkelompokan anggaran yang fokus untuk belanja daerah guna belanja aparatur dan belanja publik. Pertanggungjawaban kepada publik merupakan tuntutan yang harus dipenuhi, Berdasarkan uraian tersebut, dilakukan penelitian. Mengingat keterbatasan dokumen yang diperoleh, maka dilakukan Kajian kinerja belanja daerah tahun 2013. Penelitian ini ditetapkan judul "Transformasi Kinerja Belanja Daerah Pemerintah Provinsi Kalimantan Timur".

\section{Rencana Pendapatan Daerah pada APBD Kaltim Tahun 2009 -2013}

Secara nominal target Pendapatan Daerah pada APBD Provinsi Kalimantan Timur dari tahun ke tahun mengalami peningkatan yang cukup signifikan Tabel 2 menunjukkan di tahun 2009 sebesar Rp. 5,01 triliun menjadi dua kali lipat lebih yaitu sebesar Rp. 13 triliun di tahun 2013 atau rata-rata meningkat sebesar 18,68\% per tahun. Peningkatan ini selain berasal dari dana perimbangan yang meningkat rata-rata sebesar $12,94 \%$ per tahun dibandingkan tahun 2009, juga berasal dari kenaikan Pendapatan Asli Daerah (PAD) yang naik cukup signifikan, target PAD pada tahun 2009 sebesarRp. 1,58 triliun, pada tahun 2013 rata-rata naik sebesar $28,68 \%$ per tahun menjadi Rp. 5,60 triliun, sedangkan target Lain-Lain PAD yang Sah pada tahun 2009 sebesar Rp. 0,28 triliun naik rata-rata 8,50\% per tahun menjadi Rp 0,44 triliun pada tahun 2013.

Komposisi Pendapatan Daerah pada APBD Provinsi Kalimantan Timur tahun 2013 dapat dibagi pada 3 (tiga) bagian utama yaitu PAD, Dana Perimbangan dan Lain-lain 
PAD yang Sah. Grafik 5.1 menunjukkan besarnya jumlah uang dan persentase dari Pendapatan Daerah pada APBD Provinsi Kalimantan Timur pada Tahun 2013. Terlihat bahwa Dana Perimbangan masih mendominasi Pendapatan Daerah Provinsi Kalimantan Timur yaitu sebesar Rp. 5,77 triliun atau sebesar 49\% disusul oleh Pendapatan Asli Daerah (PAD) sebesar Rp. 5,60 triliun atau sebesar 47\% sedangkan Lain-Lain Pendapatan yang Sah hanya sebesar Rp. 0,42 triliun atau sebesar 4\% sebagaimana diagram 1 .

Diagram 1 Komposisi Pendapatan Daerah pada APBD

Provinsi Kalimantan Timur Tahun 2013 (jutaan rupiah)

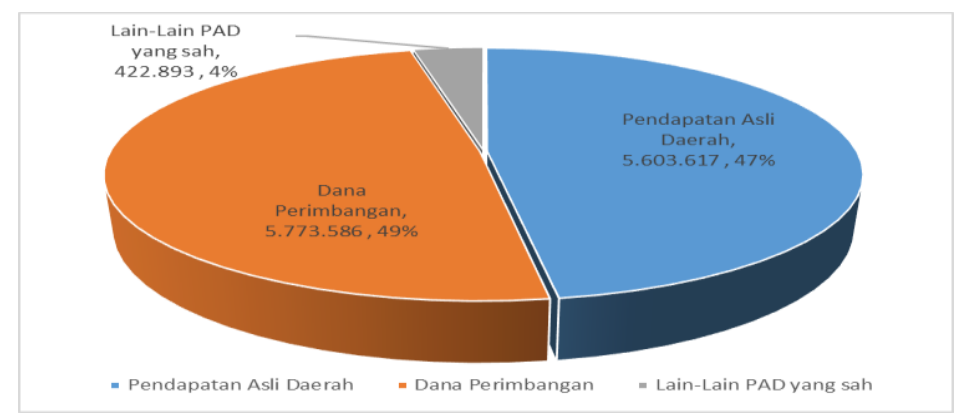

\section{Realisasi Pendapatan Daerah pada APBD Kaltim Tahun 2009 -2013}

Secara Nominal Realisasi Pendapatan Daerah pada APBD Provinsi Kalimantan Timur dari tahun ke tahun Tabel 5.2 STRUKTUR REALISASI PENDAPATAN PROVINSI KALTIM TAHUN 2008-2013

\begin{tabular}{|c|c|c|c|c|c|c|}
\hline No & Uraian & 2009 & 2010 & 2011 & 2012 & $\begin{array}{c}\text { Rata-Rata } \\
\text { Pertumbuhan } \\
\% \\
\end{array}$ \\
\hline 1 & Pendapatan & 5.348.926.283.427 & 7.041.040.890.545 & 9.819.128.719.916 & 11.904.745.269.325 & $22,14 \%$ \\
\hline 1,1 & Pendapatan Asli Daerah & 2.208.309.129.327 & 2.711.299.563.203 & 4.503.238.821.150 & 5.409 .949 .386 .546 & $25,11 \%$ \\
\hline 1.1.1 & Pajak Daerah & 1.539 .702 .679 .787 & 2.023.934.390.285 & 3.679.366.875.394 & 4.486.404.585.941 & $30,65 \%$ \\
\hline 1.1 .2 & Retribusi Daerah & 5.621 .678 .108 & 10.787 .074 .050 & 13.699.032.147 & 22.495 .631 .490 & $41,44 \%$ \\
\hline 1.1 .3 & Hasil Pengelolaan Keuangan Daerah yang dipisahkan & 121.104.217.782 & 137.612 .246 .338 & 215.652 .586 .910 & 208.293.800.917 & $14,52 \%$ \\
\hline 1.1 .4 & Lain-lain PAD yang sah & 541.880 .553 .651 & 538.965 .852 .531 & 594.520 .326 .699 & 692.755 .368 .198 & $6,33 \%$ \\
\hline 1,2 & Dana Perimbangan & 3.122.061.458.764 & 4.308.464.374.842 & 5.295.875.915.224 & 6.089 .860 .849 .779 & $18,18 \%$ \\
\hline 1.2 .1 & Dana Bagi Hasil Pajak/bagi hasil bukan pajak & 3.100 .091 .131 .764 & 4.274 .656 .662 .342 & 5.206 .240 .970 .224 & 5.984.332.194.779 & $17,87 \%$ \\
\hline 1.2 .2 & DAU & 17.867 .202 .000 & - & 51.446 .845 .000 & 52.637 .761 .000 & $31,01 \%$ \\
\hline 1.2 .3 & DAK & 3.811 .000 .000 & 33.643 .200 .000 & 38.188 .100 .000 & 34.616 .130 .000 & $73,60 \%$ \\
\hline 1.2 .4 & Dana Penyesuaian & 292.125 .000 & 164.512 .500 & - & - & $-100,00 \%$ \\
\hline 1.2 .5 & Dana Insentif Daerah & - & - & - & 18.274 .764 .000 & \\
\hline 1,3 & Lain-Lain PAD yang sah & 18.555 .695 .336 & 21.276 .952 .500 & 20.013.983.542 & 404.935 .033 .000 & $116,14 \%$ \\
\hline 1.3 .1 & Pendapatan Hibah dari Pemerintah & 1.752 .900 .236 & 926.582 .500 & 328.500 .000 & - & $-100,00 \%$ \\
\hline 1.3 .2 & Pendapatan Hibah dari Kelompok Masyarakat & 6.302 .795 .100 & 11.200 .370 .000 & 885.799 .042 & 12.890 .915 .000 & $19,59 \%$ \\
\hline 1.3 .3 & Dana Penyesuaian & - & - & 3.103 .572 .000 & 389.642 .906 .000 & $1020,48 \%$ \\
\hline 1.3 .4 & Bantuan Keuangan dari Pemda Lainnya & - & & - & - & \\
\hline 1.3 .5 & Lain-lain Pendapatan Daerah yang Sah dari Pihak Ketiga & 10.500 .000 .000 & 9.150 .000 .000 & - & - & $-100,00 \%$ \\
\hline 1.3 .6 & $\begin{array}{l}\text { Pendapatan Hibah dari Badan/Lembaga/Organisasi } \\
\text { Swasta Dalam Negeri }\end{array}$ & & 8 & 15.696 .112 .500 & 2.401 .212 .000 & $-60,89 \%$ \\
\hline
\end{tabular}




\section{Gambaran Umum Realisasi Pendapatan Daerah pada APBD Kaltim Tahun 2009 .}

2013

Secara Nominal Realisasi Pendapatan Daerah pada APBD Provinsi Kalimantan Timur dari tahun ke tahun mengalami peningkatan yang cukup signifikan Tabel 2 menunjukkan di tahun 2009 sebesar Rp. 5,35 triliun menjadi dua kali lipat lebih yaitu sebesar Rp. 11,90 triliun di tahun 2012 dan target tahun $2013 \mathrm{Rp} 13$ triliun atau rata-rata meningkat sebesar $22,14 \%$ per tahun. Peningkatan ini selain berasal dari dana perimbangan yang meningkat rata-rata sebesar $18,18 \%$ per tahun dibandingkan tahun 2009 sebesar Rp. 3,12 triliun menjadi Rp. 6,09 triliun pada tahun 2013, kenaikan yang cukup signifikan juga berasal dari kenaikan Pendapatan Asli Daerah (PAD), realisasi PAD pada tahun 2009 sebesar Rp. 2,21 triliun, pada tahun 2013 rata-rata naik sebesar 25,11\% per tahun menjadi Rp. 5,41 triliun, sedangkan realisasi Lain-Lain PAD yang Sah pada tahun 2009 sebesar Rp. 18,56 milyar naik rata-rata $116,14 \%$ per tahun menjadi Rp 404,94 milyar pada tahun 2013.

Komposisi Realisasi Pendapatan Daerah pada APBD Provinsi Kalimantan Timur tahun 2013 dapat dibagi pada 3 (tiga) bagian utama yaitu PAD, Dana Perimbangan dan Lainlain PAD yang Sah. Diagram 2 menunjukkan besarnya jumlah uang dan persentase dari Pendapatan Daerah pada APBD Provinsi Kalimantan Timur pada Tahun 2013. Terlihat bahwa Dana Perimbangan masih mendominasi Pendapatan Daerah Provinsi Kalimantan Timur yaitu sebesar Rp. 6,09 triliun atau sebesar 51\% disusul oleh Pendapatan Asli Daerah (PAD) sebesar Rp. 5,41 triliun atau sebesar 46\%

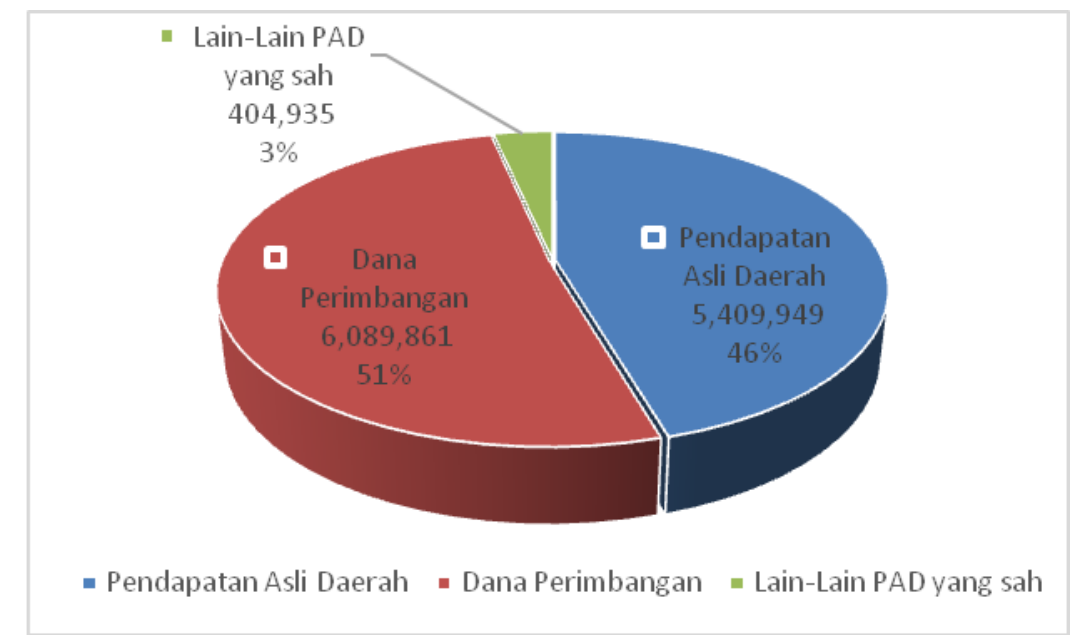




\section{a. Rasio Pajak (tax ratio)}

Rasio pajak (tax ratio) merupakan rasio yang menggambarkan perbandingan jumlah penerimaan pajak dengan Produk Domestik Regional Bruto(PDRB). Rasio pajak dapat digunakan untuk mengukur tingkat kepatuhan masyarakat dalam membayar pajak, mengukur kinerja perpajakan, dan melihat potensi pajak yang dimiliki.

PDRB sangat erat kaitannya dengan pajak daerah. PDRB menggambarkan kegiatan ekonomi masyarakat yang jika pertumbuhannya baik akan menjadi potensi penerimaan pajak diwilayah tersebut. Ada 2 jenis perhitungan PDRB yang digunakan di Indonesia, yaitu PDRB atas dasar harga berlaku dan PDRB atas dasar harga konstan.PDRB atas dasar harga berlaku merupakan nilai tambah barang dan jasa yang dihitung dengan menggunakan harga pada setiap tahun dan pada umumnya digunakan untuk melihat pergeseran struktur ekonomi yang terjadi disuatu wilayah. Sementara itu, PDRB atas dasar harga konstan menunjukkan nilai tambah barang dan jasa yang dihitung menggunakan harga pada satu tahun tertentu sebagai tahun dasar penghitungannya dan pada umumnya digunakan untuk melihat pertumbuhan ekonomi yang terjadi di suatu wilayah dari tahun ke tahun. PDRB yang akan di gunakan dalam analisis ini adalah PDRB atas dasar harga berlaku.

Perhitungan rasio pajak di Provinsi Kalimantan Timur akan memberikan gambaran hubungan antara penerimaan pajak daerah dengan PDRB, menilai kondisi Provinsi Kalimantan Timur, dan membandingkannya dengan tahun sebelumnya.

Grafik 1 Rasio Pajak Agregat Provinsi Kalimantan Timur Tahun 2009 - 2013 


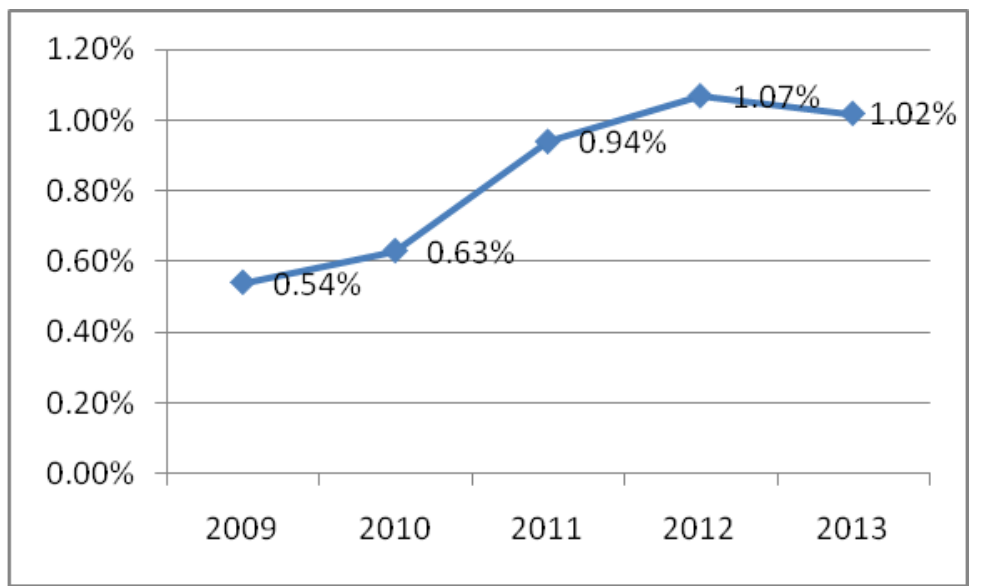

Rasio pajak agregat Provinsi Kalimantan Timur selama lima tahun mengalami peningkatan, artinya laju pertumbuhan potensi pajak diikuti dengan pertumbuhan realisasi pembayaran pajak yang dilakukan oleh masyarakat Kaltim.

Potensi pajak yang pertumbuhannya tinggi memberi dampak yang positif bila diikuti dengan penerimaan di sector pajak sehingga dapat menambah PAD yang pada gilirannya dapat menggeser struktur APBD yang masih didominasi oleh Dana Perimbangan, sehingga kemandirian fiskal Provinsi Kalimantan Timur dapat ditingkatkan. Akan tetepi penerimaan pajak di Provinsi Kalimantan Timur lebih rendah bila dibandingkan dengan pertumbuhan PDRB disebabkan banyaknya perusahaan yang melakukan usaha di Kalimantan Timur adalah sector pertambangan yang merupakan sumber penerimaan Negara yang selanjutnya akan menjadi sumber pendapatan dana bagi hasil sumber daya alam (DBH SDA) yang dalam rasio ini tidak diperhitungkan.

\section{b. Rasio Pajak Per Kapita (tax per capita)}

Pajak perkapita (taxpercapita) memang belum banyak digunakan dalam menghitung tingkat keberhasilan pajak sebagai sumber pendapatan daerah.Namun, pajak perkapita dapat digunakan sebagai alternatif alat hitung efektifitas pemungutan pajak daerah.Pajak perkapita merupakan perbandingan antara jumlah penerimaan pajak yang dihasilkan suatu daerah dengan jumlah penduduknya. Pajak per kapita menunjukkan kontribusi setiap pendudukpada pajak daerah. 
Rasio pajak per PDB merupakan ukuran yang paling umum digunakan. Namun, semakin tinggi tingkat persentase pajak akan semakin menurunkan GDP penduduk setempat sehingga ukuran tersebut akan dapat terlihat bias.Untuk tujuan tertentu, seperti statistik yang lebih baik, pajak per kapita (tax per person) dapat digunakan. Pajak perkapita dapat dihitung dengan mengalikan rasio pajak dengan PDRB perkapita sehingga diperoleh

pajak/PDRBxPDRB/personal= pajak/personal

Grafik 2 Realisasi Pajak Per Kapita Agregat Provinsi Kalimantan Timur Tahun 20092013

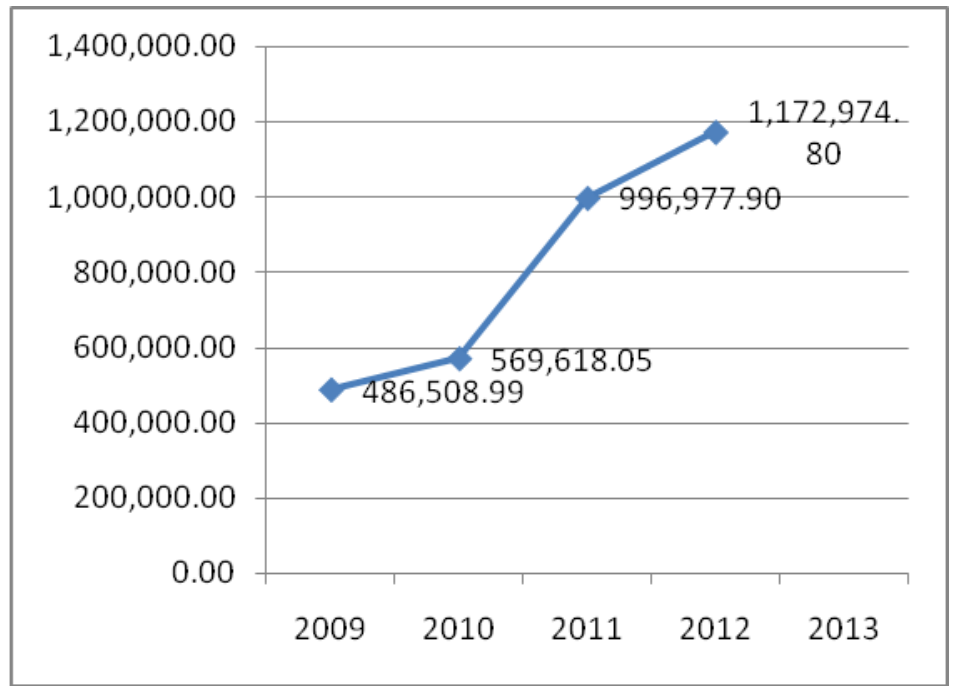

Pajak per kapita secara keseluruhan yang dapat dilihat pada Grafik 2 menunjukkan bahwa pajak perkapita Provinsi Kalimantan Timur sangat tinggi, yaitu sebesar Rp 1.172.974 per kapita per tahun pada tahun 2012, yang berarti setiap penduduk yang ada di Provinsi Kalimantan Timur pada tahun 2012 memiliki kontribusi sebesar Rp 1.172.974 dalam menghasilkan penerimaan daerah berupa pajak daerah. Hal ini 
disebabkan oleh besarnya basis pajak daerah dan jumlah penduduk yang masih sedikit.

\section{c. Ketergantungan Fiskal}

Ruang fiscal (fiscal space) merupakan suatu konsep untuk mengukur fleksibilitas yang dimiliki pemerintah daerah dalam mengalokasikan APBD untuk membiayai kegiatan yang menjadi prioritas daerah. Semakin besar ruang fiscal yang dimiliki suatu daerah maka akan semakin besar pula fleksibilitas yang dimiliki oleh pemerintah daerah untuk mengalokasikan belanjanya pada kegiatan-kegiatan yang menjadi prioritas daerah seperti pembangunan infrastruktur daerah.Ruangfiscal diperoleh dengan cara mengurangi total Pendapatan Daerah dengan pendapatan yang sudah ditentukan penggunaannya (earmarked) serta belanja yang sifatnya mengikat seperti Belanja Pegawai dan Belanja Bunga.

Efektifitas dan efisiensi penggunaan anggaran didaerah juga mendukung terciptanya ruang fiskal.Pemerintah daerah diharapkan dapat memanfaatkan ruang fiscal yang dimiliki untuk meningkatkan pertumbuhan ekonomi didaerahnya.Selain itu, pemerintah daerah juga diharapkan dapat membuat kebijakan yang mampu menciptakan iklim perekonomian yang kondusif.Sektor riil seperti perdagangan dan perkembangan usaha kecil dan menengah yang selamaini masih belum optimal, harus diberi dukungan kebijakan dari pemerintah.

Grafik 3 Ruang Fiscal Realisasi APBD Provinsi Kalimantan Timur Tahun 2009 - 2013

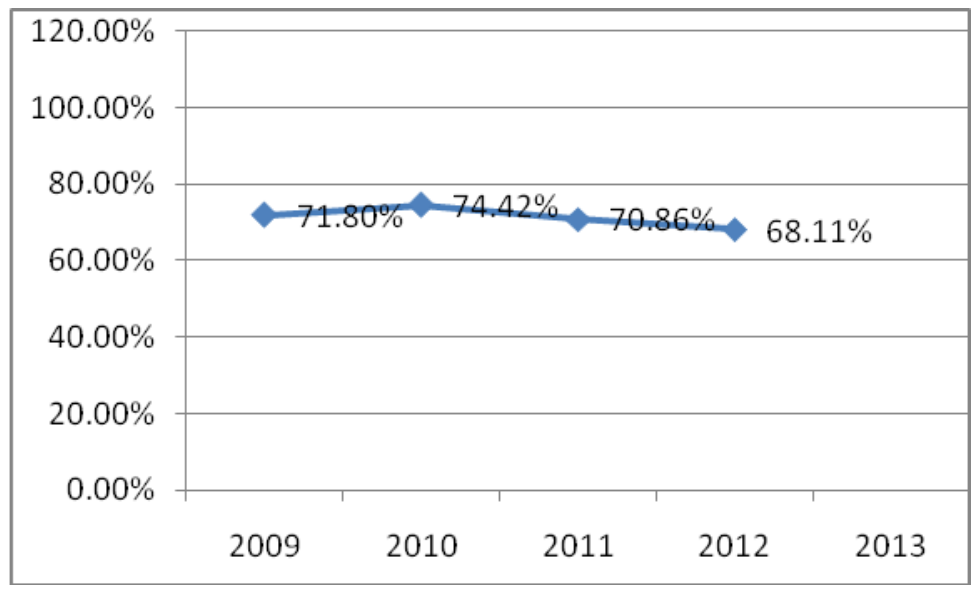


Ruang fiscal Provinsi Kalimantan Timur cukup besar, pada tahun 2012 sebesar $68,11 \%$. Tingginya angka ini dapat disebabkan oleh pendapatan yang tidak dibatasi penggunaannya yang didominasi oleh sektor pertambangan dan migas serta sector kehutanan dan perkebunan.

Pemerintah Provinsi Kalimantan Timur perlu memanfaatkan ruang fiscal yang tinggi tersebut untuk kegiatan yang dapat memacu pembangunan di Kalimantan Timur sehingga diharapkan dengan itu dapat memacu pertumbuhan ekonomi. Lebih lanjut, dengan pertumbuhan ekonomi yang tinggi pada sektor-sektor tertentujuga akan meningkatkan potensi penerimaan pajak daerah.

\section{d. Belanja Daerah}

Sejak dilaksanakannya kebijakan otonomi daerah dan desentralisasi fiscal padatahun2001, anggaran Belanja Daerah dari tahun ketahun menunjukkan peningkatan yang cukup signifikan dari sisi besaran alokasi dana yang dibelanjakan. Belanja Daerah digunakan untuk pelaksanaan urusan pemerintahan yang menjadi kewenangan provinsi atau kabupaten/kota yangterdiri dari urusan wajib dan urusan pilihan yang ditetapkan dengan ketentuan perundang-undangan.

Anggaran Belanja Daerah akan mempunyai peran riil dalam peningkatan kualitas layanan publik dan sekaligus menjadi stimulus bagi perekonomian daerah apabila terealisasi dengan baik. Dengan demikian, secara ideal seharusnya Belanja Daerah dapat menjadi komponen yang cukup berperan dalam peningkatan akses masyarakat terhadap sumber-sumber daya ekonomi yang bermanfaat bagi kesejahteraan masyarakat. Pada gilirannya, apabila kesejahteraan masyarakat telah meningkat maka diharapkan akan berdampak kepada perekonomian daerah secara luas.

Untuk menggambarkan seberapa besar belanja pemerintah daerah yang digunakan dalam upaya untuk menyejahterakan penduduk disuatu daerah, dapat digunakan berbagai macam tool misalnya dengan pengukuran rasio Belanja Daerah terhadap jumlah penduduk (Belanja Daerah perkapita).Semakin besar nilai rasio Belanja 
Daerah perkapita, semakin besar belanja yang dikeluarkan untuk menyejahterakan satu orang penduduk wilayah tersebut sehingga semakin besar kemungkinan tercapainya. Sebaliknya, semakin kecil angka rasionya, semakin kecil dana yang disediakan pemda untuk menyejahterakan penduduknya.

Namun demikian, rasio ini sebaiknya juga dirinci lagi menjadi perjenis belanja sehingga akan lebih memperlihatkan kontribusi dari setiap jenis belanja sebagai faktor yang mendorong peningkatan kualitas layanan publik. Berbagai macam pengukuran rasio belanja akan dipaparkan pada bab ini. Pada prinsipnya, dalam tataran kebijakan, untuk menuju pelaksanaan Belanja Daerah yang berdampak positif kepada masyarakat perlu diupayakan agar pemerintah daerah mempercepat realisasi belanjanya dan menjalankan kebijakan belanja yang baik, antara lain dengan mendorong agar proses penetapan Perda APBD dapat dilakukan secara tepat waktu, menetapkan anggaran Belanja Modal yang lebih besar dan tepat sasaran, mempertajam penggunaan anggaran Belanja Pegawai, dan sebagainya.

\section{e. Rasio Belanja Pegawai Terhadap Total Belanja Daerah}

Rasio Belanja Pegawai terhadap total Belanja Daerah digunakan untuk mengetahui proporsi Belanja Pegawai terhadap total Belanja Daerah. Data Belanja Pegawai yang digunakan adalah Belanja Pegawai langsung dan Belanja Pegawai tidak langsung.Rasio ini menggambarkan rasio Belanja Pegawai terhadap Belanja Daerah.Semakin tinggi angka rasionya maka semakin besar proporsi APBDyang dialokasikan untuk Belanja Pegawai. Begitu pula sebaliknya, semakin kecil angka rasio Belanja Pegawai maka semakin kecil proporsi APBD yang dialokasikan untuk Belanja Pegawai APBD

Grafik 4 Rasio Belanja Pegawai terhadap Belanja Daerah 


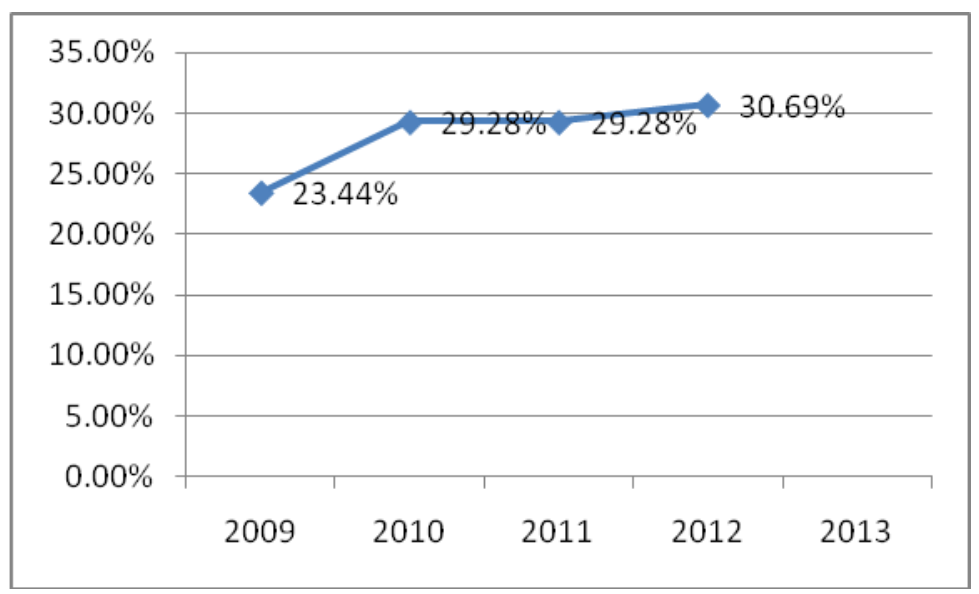

Grafik 4 di atas menunjukkan bahwa rasio belanja pegawai terhadap Belanja Daerah Provinsi Kalimantan Timur pada tahun 2012 adalah 30,69\%, keleluasaan anggaran Provinsi Kalimantan Timur cukup tinggi karena hanya sepertiga yang digunakan untuk pembiayaan rutin belanja pegawai dan sisanya sebesar dua pertiga dapat digunakan untuk belanja modal, belanja bantuan sosial dan membantu anggaran Kabupaten/Kota di Provinsi Kalimantan Timur. Diharapkan dengan keleluasaan anggaran di Provinsi Kalimantan Timur dapat dimanfaatkan pembiayaan/kegiatan non pegawai, untuk membangun infrastruktur, sumber daya manusia dan percepatan pertumbuhan ekonomi.

\section{f. Rasio Belanja Modal terhadap Belanja Daerah}

Rasio Belanja Modal terhadap total Belanja Daerah mencerminkan porsi Belanja Daerah yang dibelanjakan untuk membiayai Belanja Modal.Belanja Modal ditambah belanja barang dan jasa merupakan belanja pemerintah daerah yang mempunyai pengaruh signifikan terhadap pertumbuhan ekonomi suatu daerah, di samping pengaruh dari sektor swasta, rumah tangga, dan luar negeri. Realisasi Belanja Modal akan memiliki multiplier effect dalam menggerakkan roda perekonomian daerah. Oleh Karena itu, semakin tinggi angka rasionya diharapkan akan semakin baik pengaruhnya terhadap pertumbuhan ekonomi. Sebaliknya, semakin rendah angkanya, semakin berkurang pengaruhnya terhadap pertumbuhan ekonomi. 
Grafik 5 Rasio Realisasi Belanja Modal terhadap Belanja Daerah Provinsi Kalimantan Timur Tahun 2009 -2013

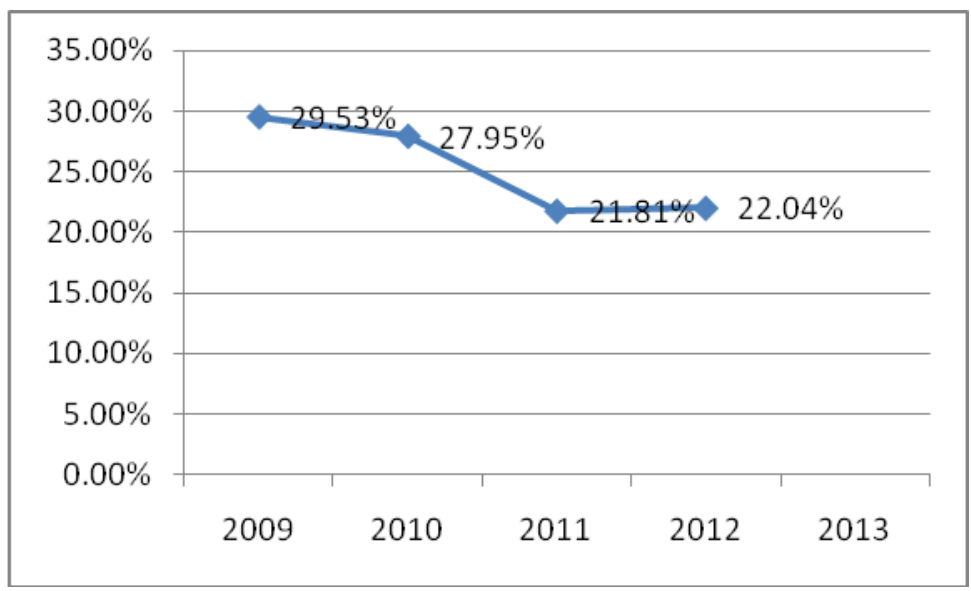

Grafik 5 menunjukkan realisasi Belanja Modal terhadap Belanja Daerah Provinsi Kalimantan Timur pada tahun 2013 sebesar 22,04\% rasio tersebut mengalami penurunan bila dibandingkan dengan realisasi belanja modal tahun 2009 dan tahun 2010 tetapi naik sedikit bila dibandingkan dengan tahun 2011 yang hanya memiliki rasio sebesar $21,81 \%$, Belanja modal yang dilakukan oleh pemerintah daerah seharusnya diperbesar guna meningkatkan kualitas dan kuantitas infrastruktur di Provinsi Kalimantan Timur sehingga laju pertumbuhan ekonomi dapat ditingkatkan dan ketertinggalan fasilitas dan infrastruktur didaerah pedalaman Kalimantan Timur dapatdiperbaiki sehingga pemerataan pembangunan dapat dinikmati oleh seluruh lapisan masyarakat Kalimantan Timur.

\section{g. Rasio Realisasi Belanja Modal terhadap Jumlah Penduduk}

Rasio Belanja Modal perkapita menunjukkan seberapa besar belanja yang dialokasikan pemerintah untuk pembangunan infrastruktur daerah perpenduduk. Rasio Belanja Modal per kapita memiliki hubungan yang erat dengan pertumbuhan ekonomi karena Belanja Modal merupakan salah satu jenis belanja pemerintah yang menjadi pendorong pertumbuhan ekonomi. Rasio ini bermanfaat untuk menunjukkan perhatian pemerintah dalam meningkatkan perekonomian penduduknya dari pembangunan infrastruktur yang dikeluarkan. 
Grafik 6 menunjukkan realisasi Belanja Modal Per Kapita Provinsi Kalimantan Timur pada tahun 2012 mengalami kenaikan dari Tahun 2011 yang hanya Rp. 481.288 per kapita menjadi Rp. 653.401 per kapita pada tahun 2012 dan Rp 674,201tahun 2013. Hal ini menunjukkan adanya peningkata perhatian Pemerintah Propinsi Kalimantan Timr dalam meningkatkan Insfrastruktur di Kalimantan Timur guna percepatan pertumbuhan ekonomi Kalimantan Timur.

Grafik 6 Rasio Realisasi Belanja Modal Provinsi Kalimantan Timur Tahun 2009 2013 terhadap jumlah penduduk (Rp)

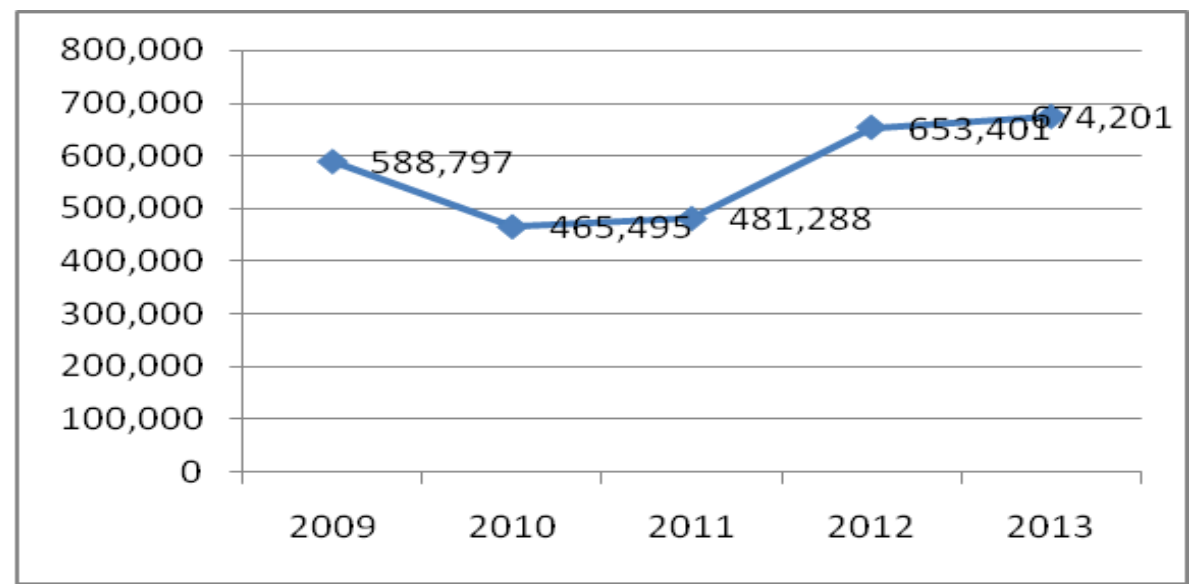

\section{h. Rasio Belanja Bantuan Sosial terhadap Belanja Daerah}

Belanja Bantuan Sosial merupakan salah satu posdalam belanja tidak langsung.Secara definisi, Bantuan Sosial adalah pemberian bantuan yang sifatnya tidak secara terus menerus dan selektif dalam bentuk uang/barang kepada masyarakat atau organisasi profesi yang bertujuan untuk kepentingan umum. Dalam Bantuan Sosial termasuk antara lain bantuan partai politik sesuai peraturan perundangundangan yang berlaku.

Bantuan Sosial ini berpotensi menimbulkan tumpang tindih kegiatan dengan kegiatan yang dilakukan oleh satuan kerja perangkat daerah (SKPD), dimana keduanya menggunakan dana dari APBD. Sebagai contoh, Bantuan Sosial kepada masyarakat dilingkungan kumuh, pondok pesantren, bantuan untuk bidang sanitasi, penyediaan akses air bersih,dan sebagainya yang juga dilaksanakan oleh SKPD. Oleh karena itu, perlu adanya pemantauan terhadap jumlah anggaran yang dialokasikan untuk 
Belanja Bantuan Sosial. Agar pengelolaan Belanja Bantuan Sosial dilaksanakan secara transparan dan akuntabel, saat ini Pemerintah telah menetapkan pengaturannya dalam Peraturan Menteri Dalam Negeri Nomor 32 Tahun 2011 tentang Pedoman Pemberian Hibah dan Bantuan Sosial Yang Bersumber Dari Anggaran Pendapatan dan Belanja Daerah.

Rasio Belanja Bantuan Sosial terhadap total Belanja Daerah mencerminkan porsi Belanja Daerah yang dibelanjakan untuk Belanja Bantuan Sosial. Semakin tinggi angka rasionya maka semakin besar proporsi APBD yang dialokasikan untuk Belanja Bantuan Sosial dan begitu sebaliknya semakin kecil angka rasio Belanja Bantuan Sosial maka semakin kecil pula proporsi APBD yang dialokasikan untuk Belanja Bantuan Sosial

Grafik 7 Realisasi Rasio Belanja Bantuan Sosial terhadap Belanja Daerah Provinsi Kalimantan Timur Tahun 2009 - 2013

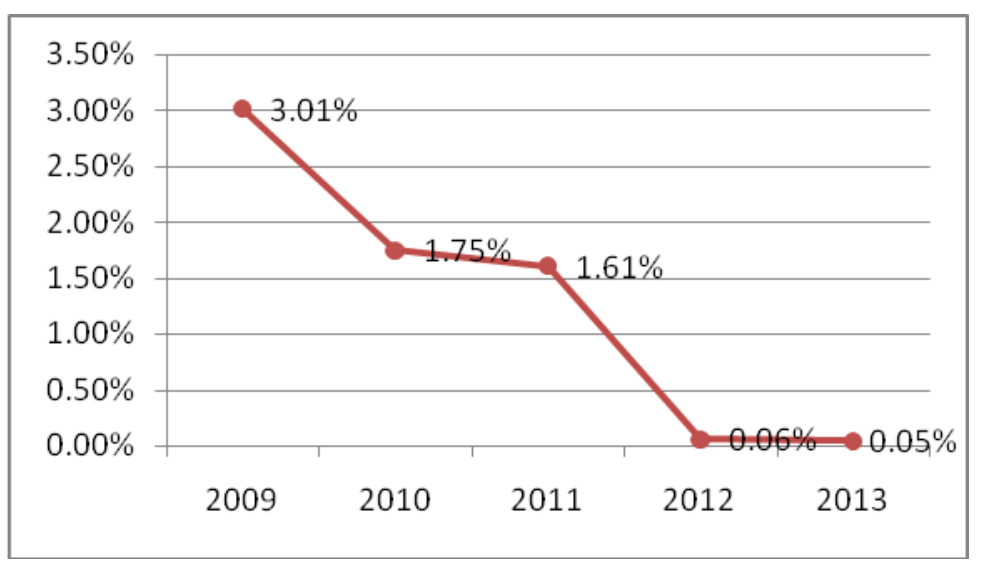

Dari grafik 7 di atas diketahui bahwa realisasi rasio Belanja Bantuan Sosial terhadap Belanja Daerah Provinsi Kalimantan Timur dari tahun 2009 sampai Tahun 2012 mengalami penurunan yang cukup signifikan, pada tahun 2009 realisasi rasio Benja 
Bantuan Sosial terhadap Belanja Daerah sebesar 3,01\% turun menjadi 0,06\% pada tahun 2012 dan 0.08 tahun 2013. Pemberian bantuan sosial kepada masyarakat Kalimantan Timur oleh pemerintah prvinsi dilakukan secara selektif dan berorientasi pada peningkatan pertumbuhan sector riil, sehingga bantuan sosial hanya sebagai strimulus bagi masyarakat yang membutuhkan dan menghindari adanya ketergantungan masyarakat terhadap bantuan sosial karena sifatnya hanya sementara dan tidak terus-menerus.

\section{i. Perhitungan Anggaran}

Pendapatan daerah tahun 2009 sebesar Rp. 5,01 triliun menjadi dua kali lipat lebih yaitu sebesar Rp. 11,80 triliun di tahun 2013 atau rata-rata meningkat sebesar 18,68\% per tahun. Peningkatan ini selain berasal dari dana perimbangan yang meningkat ratarata sebesar $12,94 \%$ per tahun dibandingkan tahun 2009, juga berasal dari kenaikan Pendapatan Asli Daerah (PAD) yang naik cukup signifikan, target PAD pada tahun 2009 sebesarRp. 1,58 triliun, pada tahun 2013 rata-rata naik sebesar 28,68\% per tahun menjadi Rp. 5,60 triliun, sedangkan target Lain-Lain PAD yang Sah pada tahun 2009 sebesar Rp. 0,28 triliun naik rata-rata 8,50\% per tahun menjadi Rp 0,44 triliun pada tahun 2013 .

Sedangkan dari sudut Belanja Pegawai terhadap total Belanja Daerah digunakan untuk mengetahui proporsi Belanja Pegawai terhadap total Belanja Daerah. Data Belanja Pegawai yang digunakan adalah Belanja Pegawai langsung dan Belanja Pegawai tidak langsung. Terhadap Belanja Daerah. Rasio belanja pegawai terhadap Belanja Daerah Provinsi Kalimantan Timur pada tahun 2013 adalah 30,69\%, keleluasaan anggaran Provinsi Kalimantan Timur cukup tinggi karena hanya sepertiga yang digunakan untuk pembiayaan rutin belanja pegawai dan sisanya sebesar dua pertiga dapat digunakan untuk belanja modal, belanja bantuan sosial dan membantu anggaran Kabupaten/Kota di Provinsi Kalimantan Timur. Diharapkan dengan keleluasaan anggaran di Provinsi Kalimantan Timur dapat dimanfaatkan pembiayaan / kegiatan non pegawai, untuk membangun infrastruktur, sumber daya manusia dan percepatan pertumbuhan ekonomi. 
Realisasi Belanja Modal terhadap Belanja Daerah Provinsi Kalimantan Timur pada tahun 2013 sebesar 22,04\% rasio tersebut mengalami penurunan bila dibandingkan dengan realisasi belanja modal tahun 2009 dan tahun 2010 tetapi naik sedikit bila dibandingkan dengan tahun 2011 yang hanya memiliki rasio sebesar $21,81 \%$, Belanja modal yang dilakukan oleh pemerintah daerah seharusnya diperbesar guna meningkatkan kualitas dan kuantitas infrastruktur di Provinsi Kalimantan Timur sehingga laju pertumbuhan ekonomi dapat ditingkatkan dan ketertinggalan fasilitas dan infrastruktur didaerah pedalaman Kalimantan Timur dapat diperbaiki sehingga pemerataan pembangunan dapat dinikmati oleh seluruh lapisan masyarakat Kalimantan Timur.

Realisasi Belanja Modal Per Kapita Provinsi Kalimantan Timur pada tahun 2012 mengalami kenaikan dari Tahun 2011 yang hanya Rp. 481.288 per kapita menjadi Rp. 653.401 per kapita pada tahun 2013. Hal ini menunjukkan adanya peningkata perhatian Pemerintah Propinsi Kalimantan Timr dalam meningkatkan Insfrastruktur di Kalimantan Timur guna percepatan pertumbuhan ekonomi Kalimantan Timur.

Realisasi rasio Belanja Bantuan Sosial terhadap Belanja Daerah Provinsi Kalimantan Timur dari tahun 2009 sampai Tahun 2013 mengalami penurunan yang cukup signifikan, pada tahun 2009 realisasi rasio Benja Bantuan Sosial terhadap Belanja Daerah sebesar 3,01\% turun menjadi 0,06\% pada tahun 2012 dan 0.08 tahun 2013 Pemberian bantuan sosial kepada masyarakat Kalimantan Timur oleh pemerintah prvinsi dilakukan secara selektif dan berorientasi pada peningkatan pertumbuhan sector riil, sehingga bantuan sosial hanya sebagai strimulus bagi masyarakat yang membutuhkan dan menghindari adanya ketergantungan masyarakat terhadap bantuan sosial karena sifatnya hanya sementara dan tidak terus-menerus.

\section{ANALISIS DAN PEMBAHASAN}

\section{Pencapaian Kinerja}

\section{a. Pendapatan Daerah}

Pendapatan Daerah tahun 2009 sebesar Rp. 5,01 triliun menjadi dua kali lipat lebih yaitu sebesar Rp. 11,80 triliun di tahun 2013 atau rata-rata meningkat sebesar $18,68 \%$ per tahun. Peningkatan ini selain berasal dari dana perimbangan 
yang meningkat rata-rata sebesar $12,94 \%$ per tahun dibandingkan tahun 2009, juga berasal dari kenaikan Pendapatan Asli Daerah (PAD) yang naik cukup signifikan, target PAD pada tahun 2009 sebesarRp. 1,58 triliun, pada tahun 2013 rata-rata naik sebesar $28,68 \%$ per tahun menjadi Rp. 5,60 triliun, sedangkan target Lain-Lain PAD yang Sah pada tahun 2009 sebesar Rp. 0,28 triliun naik rata-rata 8,50\% per tahun menjadi Rp 0,44 triliun pada tahun 2013.

Komposisi Pendapatan Daerah pada APBD Provinsi Kalimantan Timur tahun 2013 dapat dibagi pada 3 (tiga) bagian utama yaitu PAD, Dana Perimbangan dan Lain-lain PAD yang Sah. menunjukkan besarnya jumlah uang dan persentase dari Pendapatan Daerah pada APBD Provinsi Kalimantan Timur pada Tahun 2013. Terlihat bahwa Dana Perimbangan masih mendominasi Pendapatan Daerah Provinsi Kalimantan Timur yaitu sebesar Rp. 5,77 triliun atau sebesar 49\% disusul oleh Pendapatan Asli Daerah (PAD) sebesar Rp. 5,60 triliun atau sebesar 47\% sedangkan Lain-Lain Pendapatan yang Sah hanya sebesar Rp. 0,42 triliun atau sebesar $4 \%$.

Potensi pajak yang pertumbuhannya tinggi memberi dampak yang positif bila diikuti dengan penerimaan di sector pajak sehingga dapat menambah PAD yang pada gilirannya dapat menggeser struktur APBD yang masih didominasi oleh Dana Perimbangan, sehingga kemandirian fiskal Provinsi Kalimantan Timur dapat ditingkatkan. Akan tetpi penerimaan pajak di Provinsi Kalimantan Timur lebih rendah bila dibandingkan dengan pertumbuhan PDRB disebabkan banyaknya perusahaan yang melakukan usaha di Kalimantan Timur adalah sector pertambangan yang merupakan sumber penerimaan Negara yang selanjutnya akan menjadi sumber pendapatan dana bagi hasil sumber daya alam (DBH SDA) yang dalam rasio ini tidak diperhitungkan.

Pajak per kapita secara keseluruhan yang menunjukkan bahwa pajak perkapita Provinsi Kalimantan Timur sangat tinggi, yaitu sebesar Rp 1.172.974 per kapita per tahun pada tahun 2013, yang berarti setiap penduduk yang ada di Provinsi Kalimantan Timur pada tahun 2012 memiliki kontribusi sebesar Rp 1.172.974 dalam menghasilkan penerimaan daerah berupa pajak daerah. Hal ini 
disebabkan oleh besarnya basis pajak daerah dan jumlah penduduk yang masih sedikit.

Ruang fiscal Provinsi Kalimantan Timur cukup besar, pada tahun 2013 sebesar $68,11 \%$. Tingginya angka ini dapat disebabkan oleh pendapatan yang tidak dibatasi penggunaannya yang didominasi oleh sektor pertambangan dan migas serta sector kehutanan dan perkebunan.

Pemerintah Provinsi Kalimantan Timur perlu memanfaatkan ruang fiscal yang tinggi tersebut untuk kegiatan yang dapat memacu pembangunan di Kalimantan Timur sehingga diharapkan dengan itu dapat memacu pertumbuhan ekonomi. Lebih lanjut, dengan pertumbuhan ekonomi yang tinggi pada sektor-sektor tertentu juga akan meningkatkan potensi penerimaan pajak daerah.

\section{b. Belanja Daerah}

Rasio belanja pegawai terhadap Belanja Daerah Provinsi Kalimantan Timur pada tahun 2013 adalah 30,69\%, keleluasaan anggaran Provinsi Kalimantan Timur cukup tinggi karena hanya sepertiga yang digunakan untuk pembiayaan rutin belanja pegawai dan sisanya sebesar dua pertiga dapat digunakan untuk belanja modal, belanja bantuan sosial dan membantu anggaran Kabupaten/Kota di Provinsi Kalimantan Timur. Diharapkan dengan keleluasaan anggaran di Provinsi Kalimantan Timur dapat dimanfaatkan pembiayaan/kegiatan non pegawai, untuk membangun infrastruktur, sumber daya manusia dan percepatan pertumbuhan ekonomi.

Realisasi Belanja Modal terhadap Belanja Daerah Provinsi Kalimantan Timur pada tahun 2013 sebesar 22,04\% rasio tersebut mengalami penurunan bila dibandingkan dengan realisasi belanja modal tahun 2009 dan tahun 2010 tetapi naik sedikit bila dibandingkan dengan tahun 2011 yang hanya memiliki rasio sebesar $21,81 \%$, Belanja modal yang dilakukan oleh 
pemerintah daerah seharusnya diperbesar guna meningkatkan kualitas dan kuantitas infrastruktur di Provinsi Kalimantan Timur sehingga laju pertumbuhan ekonomi dapat ditingkatkan dan ketertinggalan fasilitas dan infrastruktur didaerah pedalaman Kalimantan Timur dapat diperbaiki sehingga pemerataan pembangunan dapat dinikmati oleh seluruh lapisan masyarakat Kalimantan Timur.

Realisasi Belanja Modal Per Kapita Provinsi Kalimantan Timur pada tahun 2012 mengalami kenaikan dari Tahun 2011 yang hanya Rp. 481.288 per kapita menjadi Rp. 653.401 per kapita pada tahun 2013. Hal ini menunjukkan adanya peningkata perhatian Pemerintah Propinsi Kalimantan Timr dalam meningkatkan Insfrastruktur di Kalimantan Timur guna percepatan pertumbuhan ekonomi Kalimantan Timur.

\section{c. Rasio Belanja Bantuan Sosial terhadap Belanja Daerah}

Realisasi rasio Benja Bantuan Sosial terhadap Belanja Daerah Provinsi Kalimantan Timur dari tahun 2009 sampai Tahun 2013 mengalami penurunan yang cukup signifikan, pada tahun 2009 realisasi rasio Benja Bantuan Sosial terhadap Belanja Daerah sebesar 3,01\% turun menjadi 0,06\% pada tahun 2012 dan 0,08 tahun 2013. Pemberian bantuan sosial kepada masyarakat Kalimantan Timur oleh pemerintah provinsi dilakukan secara selektif dan berorientasi pada peningkatan pertumbuhan sector riil, sehingga bantuan sosial hanya sebagai strimulus bagi masyarakat yang membutuhkan dan menghindari adanya ketergantungan masyarakat terhadap bantuan sosial karena sifatnya hanya sementara dan tidak terus-menerus. 


\section{DAFTAR KEPUSTAKAAN}

Undang-undang nomor 17 tahun 2003 tentangKeuangan Negara

Undang - undang nomor 1 tahun 2004 tentang Perbendahaaraan

Undang-undang nomor 33 tahun 2004 tentang Perimbangan Keuangan antara Pemerintah Pusat dan Daerah

Undang Undang Nomor 28 tahun 2009 tentang Pajak Daerah dan Retribusi Daerah Peraturan Pemerintah nomor 56 tahun 2005 tentang Sistem Informasi Keuangan Daerah

....... Sisstem Informasi Keuangan ................

Permendagri nomor 13 tahun 2006 jo 59 tahun 2007 tentang Pedoman Pengelolan Keuangan Daerah 